\title{
COMBINED UNIT FOR PREPARATION OF SOIL FOR SOWING GRAIN CROPS
}

\author{
Aslan Apazhev', Viktor Smelik ${ }^{2}$, Yuri Shekikhachev ${ }^{1}$, Liuan Hazhmetov ${ }^{1}$ \\ ${ }^{1}$ Kabardino-Balkarian State Agricultural University named after V.M. Kokov, Russia; \\ ${ }^{2}$ Saint-Petersburg State Agrarian University, Russia \\ shek-fmep@mail.ru
}

\begin{abstract}
Food security of the Russian Federation is one of the priorities of the economic and food policy. Step by step decrease in dependence of domestic agro-industrial complex on import of technologies, cars, and equipment is of great importance. While preparing the soil for sowing grain crops the machines and units, which are carrying out one definite operation, are often used. Their repeated passes on the surface of the processed field raise power expenses, lead to consolidation of the soil, emergence and development of erosive processes. In this regard further improvement of machines and units for preparation of the soil for sowing grain crops is required. For the solution of this problem the combined soil-cultivating unit providing plowing, crushing of soil blocks and mulching of a top soil is offered. The constructive and technological scheme of the combined soil-cultivating unit is proved. The method of calculation of the constructive process parameters of the specified unit is developed. Mathematical model of process of interaction of the active working body of the unit with the soil, regression models of dependence of quality of dyeing of the soil and traction resistance of the unit are received from its key parameters and operating modes (operating speed, angular speed of rotation of the drum and an angle of attack of the working body). Their optimum values are defined. It is received that use of the combined soil-cultivating unit provides for increase in maintenance of soil units of 0.025 in size- $0.001 \mathrm{~m}$, increase in porosity of the soil, decrease of dusty fraction in the contents of the soil.
\end{abstract}

Keywords: soil, processing, crops, unit, dyeing, traction resistance.

\section{Introduction}

Analyzing the design features of the modern combined soil-cultivating equipment one can come to the conclusion that the accumulated experience is of great interest at its improvement in the direction of providing a whole revolution of the layer, crushing of blocks and lumps of the soil, the vegetable remains and their parallel seal to the soil, alignment and consolidation of the soil surface.

Use of special devices, in parallel with consolidation of the processed layer (from depth 0.05$0.06 \mathrm{~m}$ ), makes additional dyeing of the soil layer and alignment of the surface of the field.

The main lacks of the combined soil-cultivating equipment with passive working bodies: need for available big strips for a turn; poor quality of preparation of average and soils for performance of sowing works. With the purpose to prepare average and heavy soils for sowing 3-5 processings are carried out with use of heavy disk harrows, or the areas are processed by plows, besides, not processed till spring, so that the falling precipitation ensures crumbling of soil blocks and lumps. This technology of preparation of soils for crops is followed by big losses of time, considerable consolidation of the soil [1], an excessive consumption of fuels and lubricants and raised labor input.

In modern conditions the problem comes forward to load power saturated high-speed wheel tractors as increase in engine capacity often is not followed by growth of traction effort.

Realization through the PTO shaft of the tractor of unused engine capacity is provided with application of active working bodies together with a plow. Besides, at passing rotation of the active working body emergence "driving force", directed towards the movement of the unit, is provided.

For the purpose of systematization and account available achievements in the field of the research of the soil-cultivating equipment having active working bodies, problems of the theory and calculation of tillage machines are considered on the example of technical means with rotational working bodies (active).

Taking into account that rotational soil-cultivating technical means, in particular, of a mill, are characterized by high power expenses, it is important to set the parameters, which would provide a minimum of power consumption for processing of the soil during theoretical researches.

\section{Materials and methods}

Researches were conducted with use of methods of the system analysis, mathematical modeling and the structural analysis of technological processes on the basis of the laws of classical mechanics, 
mathematical statistics, the theory of planning of a multiple-factor experiment. Researches were conducted according to the requirements of interstate standards and private methods. Processing of the results of the experiments is executed with use of software products MicrosoftExcel 2010, MathcadPrime 3.0.

Plowing is the most power-intensive operation in the system of processing of soils, as the share of the spent fuel is up to $50 \%$.

By numerous researches it is found that the soil, which is not destroyed when plowing under the open sun, dries and is strengthened by 5 times in 8 hours. As a result on such plowed land, especially clay soils, it is not possible to create a small lumpy structural seed bed and additional mechanical energy on destruction of soil blocks and lumps is required.

Now there is an imperative need for implementation of the moisture resource-saving technologies based on combination of several operations for one pass of the unit providing simultaneous dyeing, alignment, consolidation and mulching of the top soil.

When plowing the soil, a considerable part of energy thanks to the fact that in a fresh state the soil crumbles easier is saved. On the other hand, economy of energy consumption is reached due to reduction of the number of additional passes of soil-cultivating units across the field. The design of the combined soil-cultivating unit (Fig. 1) is developed for solution of this problem [2-10].

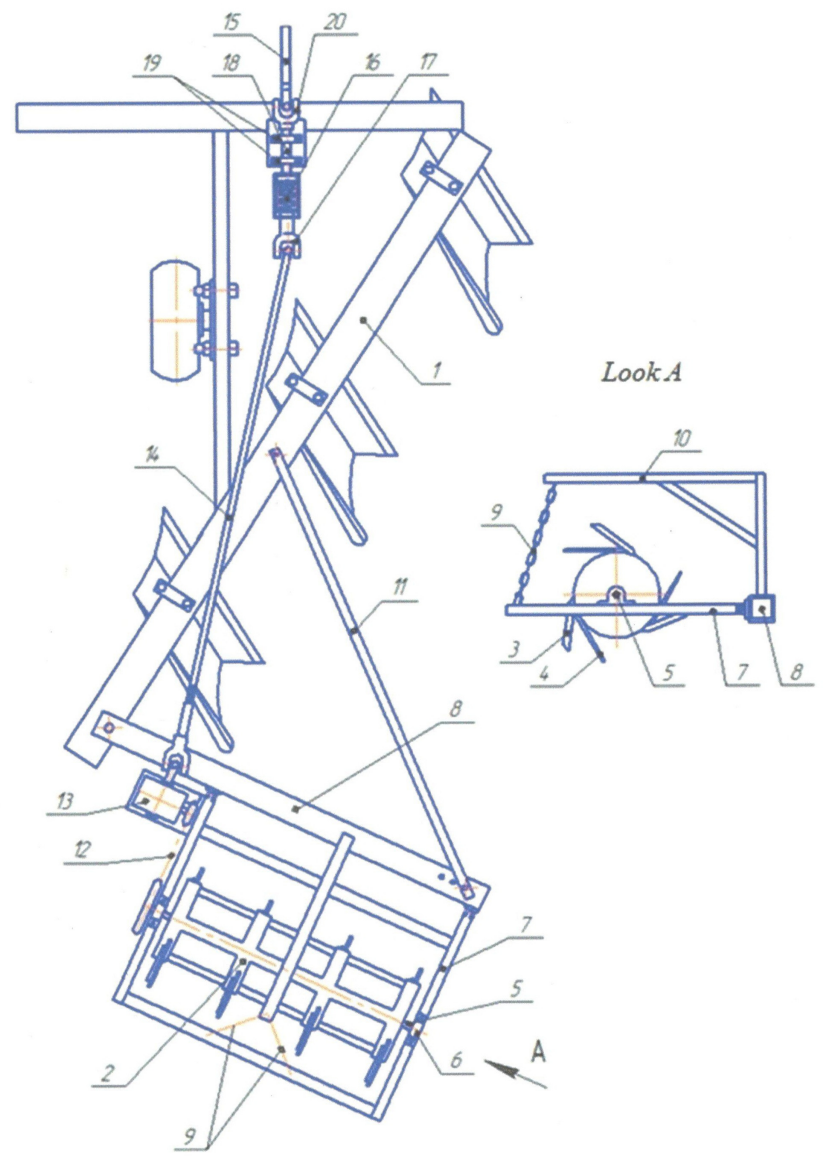

Fig. 1. Constructive and technological scheme of combined soil-cultivating unit: 1 - plow frame; 2 - drum; 3 - cutting knife; 4 - shock knife; 5 - shaft; 6,19 - bearings; 7 - drum frame; 8 - bearing beam; 9 - flexible communication; 10 - pendant; 11 -bar; 12 - chain transfer; 13 - reducer;

14 - telescopic driveshaft; 15 - leading shaft; 16 - safety mechanism; 17, 20 - crosspieces; 18 - shaft

The plow part of the unit carries out the main processing of the soil. The cutting 3 and shock 4 knives given rotation from the shaft of selection of power of the tractor destroy soil blocks, carry out their crushing. Besides, the crushed vegetable remains in the soil. Moving forward the cutting knives 3 promote relocation of the loosened soil aside, thanks to side surfaces and leveling of the furrow formed by the plow part. 
Then soil lumps get in a drum, collide with each other owing to crumble in addition. Further there is their uniform distribution on the surface of the field. For overcoming the obstacles arising in the course of work the safety mechanism 16 is provided. Its operation leads to detachment of the telescopic driveshaft 14 from the leading shaft 15 . The frame 7 is raising and overcoming an obstacle.

For the purpose of formation of the moment developing the plow counterclockwise, the active working body is provided in the design of the combined soil-cultivating unit.

Giving the knife defines as the major agrotechnical indicator - extent of dyeing of the soil. It depends on the diameter of the drum of the active working body, quantity of knives on the drum and the kinematic coefficient. $0.5 \mathrm{~m}$ calculation is made for a case, when the active working body is aggregated with the MTZ-82 tractor at a speed of $V_{\Pi}=6.35-7.75 \mathrm{~km} \cdot \mathrm{h}^{-1}$ and diameter of the reel $D_{\sigma}=0.4-$ as follows.

With

$$
\frac{V_{O K P}}{V_{\Pi}}=\lambda=4 \ldots 5,
$$

frequency of rotation will be

$$
n=\frac{60 V_{\text {OKP }}}{\pi D_{\bar{b}}}=138 \text { to } 210 \mathrm{rpm} .
$$

The feed value will be equal to

$$
S_{H}=\frac{60 V_{I I}}{n z}=0.12 \text { to } 0.21 \mathrm{~m} .
$$

Then we define the number of knives

$$
z=\frac{60 V_{\Pi}}{n S_{H}}=1.7 \text { to } 4.3 \text { pieces. }
$$

Considering the agrotechnical and power requirements, specific operating conditions of the combined arable unit and also the results of calculation, we accept the number of knives on a circle equal with rubs.

The step of the section of knives is defined by the width of the processed strip one section, the angle of attack of the active working body and its design data.

Width of the processed strip will be defined by one section as follows:

$$
B_{C}=\left(D_{B}+2 h_{O B}\right) \cos \beta_{0} \sin \gamma_{5} .
$$

where $h_{O B}-$ depth of processing of the soil, m;

$\beta_{0}$ - corner determined by the sizes of the working body and lump of the soil, hail;

$\gamma_{5}-$ angle of attack of the working body, hail.

Step of the section of knives:

$$
t_{C}=\left(D_{B}+2 h_{O B}\right) \cos \beta_{0} \operatorname{tg} \gamma_{B}
$$

The quantity of sections of knives will be determined by expression:

$$
z_{C}=1+\frac{B_{\text {ПЛ }}}{B_{C}}=1+\frac{B_{\text {ПЛ }}}{\left(D_{5}+2 h_{\text {ОБ }}\right) \cos \beta_{0} \operatorname{tg} \gamma_{5}}
$$

where $B_{\text {Пл }}-$ width of capture of the plow, $\mathrm{m}$.

Thus, the width of occupation of the active working body is determined by expression:

$$
B_{\bar{b}}=t_{C}\left(z_{C}-1\right)
$$

For definition of the corner $\tau$ installations of knives of the active working body the dependence is received: 


$$
\tau=2 \operatorname{arctg}\left[\frac{\sin \beta_{0}+\cos \beta_{0} \cos \gamma_{5} \operatorname{tg} \varphi_{\Pi K}+\sqrt{1+\cos ^{2} \gamma_{5} \operatorname{tg}^{2} \varphi_{\Pi K}}}{\cos \beta_{0}-\sin \beta_{0} \cos \gamma_{5} \operatorname{tg} \varphi_{\Pi K}}\right],
$$

where $\varphi_{\Pi K}-$ angle of friction in the "soil lump-the surface of the soil" system, hail.

Expression for definition of the corner of separation of a soil particle is received from the side surface of the knife:

$$
\varepsilon=2 \operatorname{arctg}\left[\frac{\sqrt{\omega_{5}^{2} R_{H}^{2} \cos \gamma_{5} \operatorname{ctg} \gamma_{5}+g^{2}}-1}{\omega_{5}^{2} R_{H} \cos \gamma_{5}-g}\right],
$$

where $\omega_{B}-$ angular speed of rotation of the drum, $\mathrm{s}^{-1}$;

$R_{H}$ - radius of the extreme point of a knife, m;

$g$ - acceleration of gravity, $\mathrm{m} \cdot \mathrm{s}^{-2}$.

\section{Results and discussion}

With use of expressions (9) and (10) the corresponding theoretical dependences (Fig. 2 and 3) are constructed.

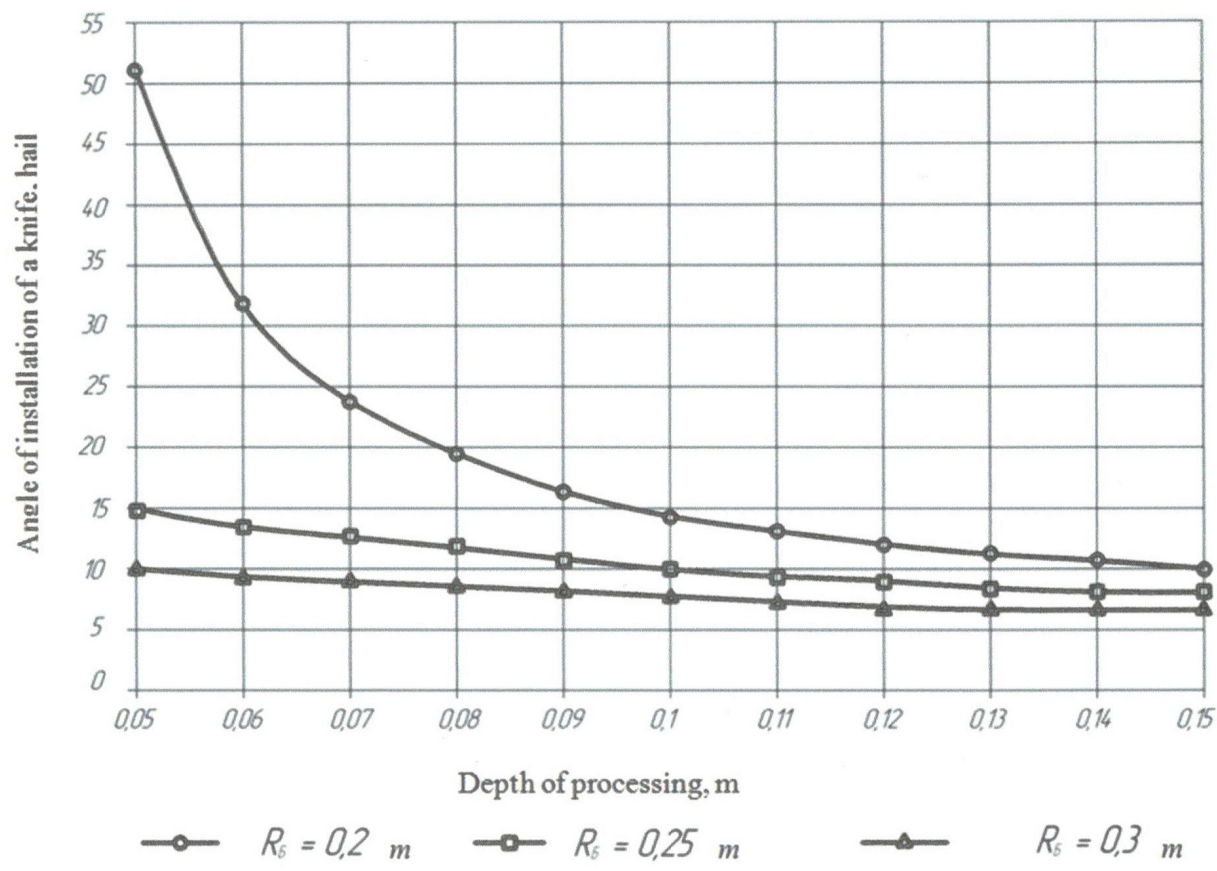

Fig. 2. Dependence of angle of installation of knife on processing depth

As a result of the conducted theoretical researches rational values of the key constructive and regime parameters of the combined soil-cultivating unit are set: speed of movement $1.5-2.0 \mathrm{~m} \cdot \mathrm{s}^{-1}$, attack angle of the operating part 20-30 , rotating speed of the reel 20-25 s${ }^{-1}$.

For establishment of the optimum constructive and regime parameters of the combined soilcultivating unit providing the maximum quality of dyeing of the soil $\left(K_{K P}, \%\right)$, a multiple-factor experiment was made, as a result of which the regression equation is received:

$$
\begin{aligned}
& K_{K P}=-1672.57+1697.041 V_{\Pi}+6.7144 \omega_{\bar{b}}+1.9769 \gamma_{\bar{L}}+0.8607 V_{\Pi} \omega_{\bar{L}}- \\
& -0.2702 V_{\Pi} \gamma_{5}-432.224 V_{\Pi}^{2}-0.2092^{2}-0.0359 \gamma_{\bar{L}}^{2}
\end{aligned}
$$

The analysis of the regression equation (11), the carried-out inspection of its coefficients by Student, Fischer and Kokhren's criteria showed that the received equation is adequate, reproduced, and its use for creation of a surface of a response Fig.4) of the studied dependence of influence of the key parameters of the combined soil-cultivating unit on quality of dyeing of the soil is possible. The maximum value of quality of dyeing $(92.3 \%)$ is reached at the following values of the varying factors: 
speed of movement of the unit of $1.98 \mathrm{~m} \cdot \mathrm{s}^{-1}$, angular speed of rotation of the drum $20.1 \mathrm{~s}^{-1}$ and angle of attack of the working body $20^{\circ}$.

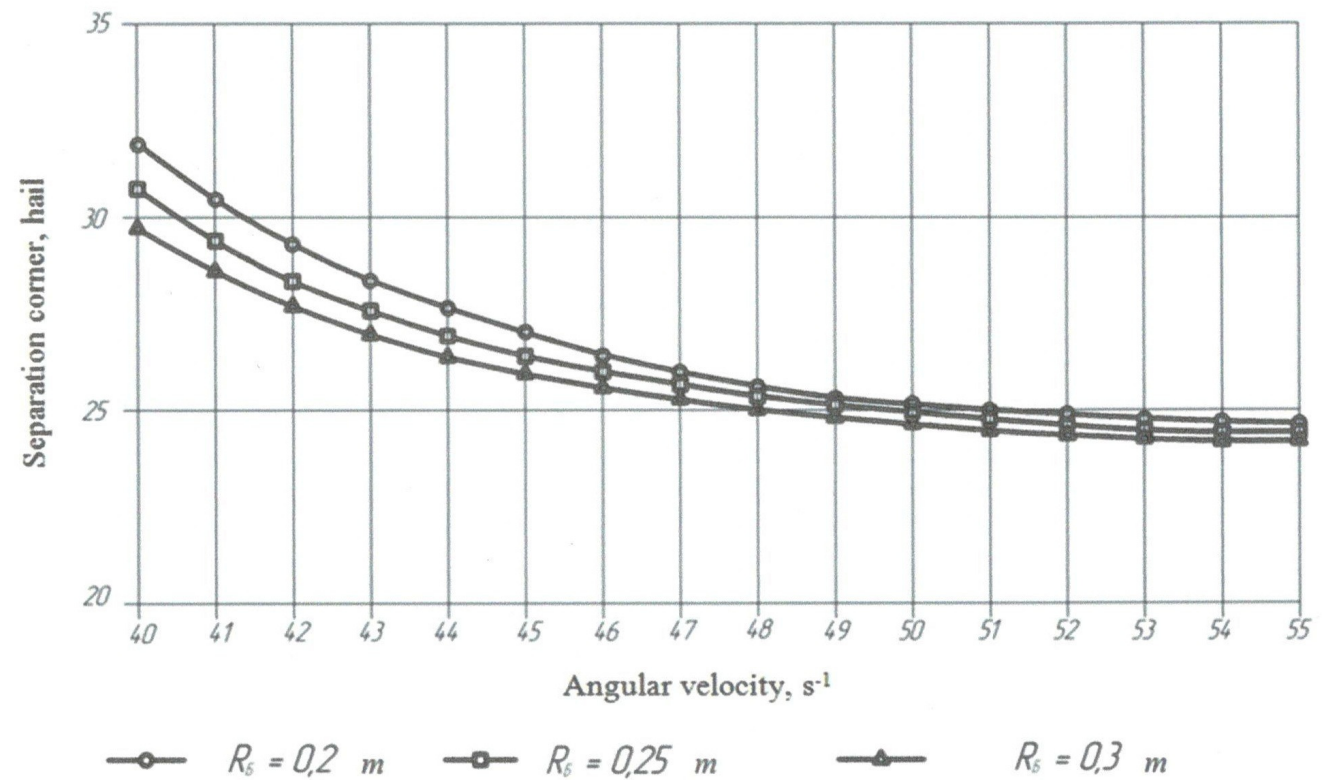

Fig. 3. Dependence of corner of separation of soil particle on side surface of knife and on angular speed of drum (with depth of processing of soil of $0.1 \mathrm{~m}$ and angle of attack $25^{\circ}$ )

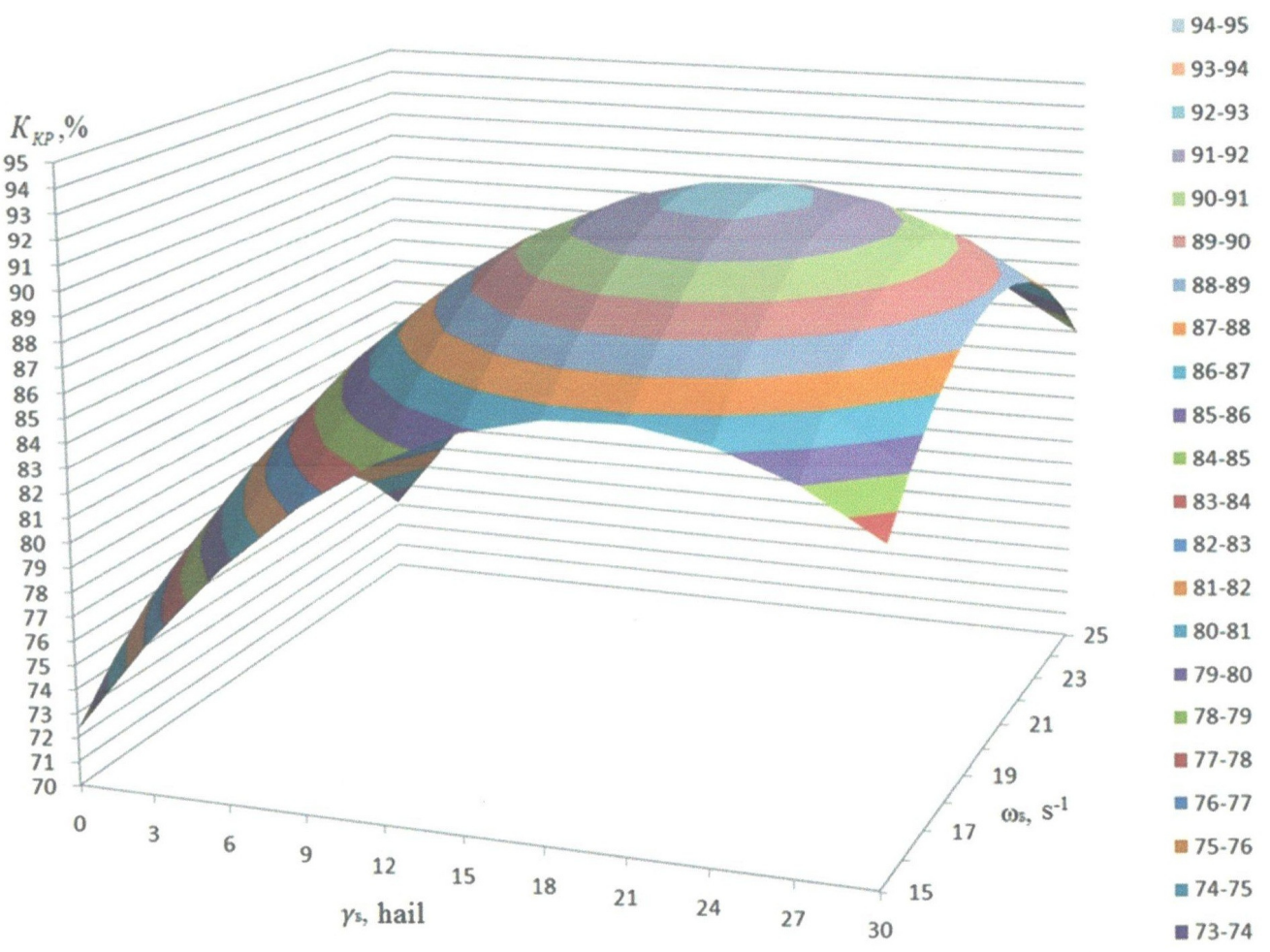

Fig. 4. Surface of response of quality of dyeing of soil from angle of attack and angular speed of rotation of drum

For establishment of the optimum constructive and regime parameters of the combined soilcultivating unit providing the minimum traction resistance of the unit the multiple-factor experiment was done, as a result of which the regression equation is received: 


$$
\begin{aligned}
& P_{T}=965.634-882.22 V_{\Pi}+6.0441 \omega_{\bar{L}}-0.8682 \gamma_{\bar{L}}+0.2357 V_{\Pi} \omega_{\bar{L}}+ \\
& +0.0679 V_{\Pi} \gamma_{B}+219.816 V_{\Pi}^{2}+0.1343_{B}^{2}+0.0195 \gamma_{\bar{L}}^{2}
\end{aligned}
$$

The analysis of the received surface of response (Fig. 5) from the studied factors showed that the minimum value of traction resistance of the unit $(15.8 \mathrm{kN})$ is reached at the following values of the varying factors: speed of movement of the unit of $1.99 \mathrm{~m} \cdot \mathrm{s}^{-1}$, angular speed of rotation of the drum $20.7 \mathrm{~s}^{-1}$ and angle of attack of the working body $19^{\circ}$.

Thus, the maximum quality of dyeing of the soil and the minimum traction resistance are reached at the speed of movement of unit 1.98-1.99 m/s, the angular speed of rotation of the drum 20.1-20.7 s $\mathrm{s}^{-1}$ and the angle of attack of the working body $190-20^{\circ}$.

The results of field researches of the combined soil-cultivating unit showed that at its use the maintenance of soil units of 0.025 in size- $0.001 \mathrm{~m}$ on 22.4-35.1\% in comparison with use of a basic complex of cars increased, the porosity of the soil increased by $24.5-26.1 \%$, contents in the soil of dusty fraction decreased by $22.4-35.1 \%$, soil density in the horizon $0-0.2 \mathrm{~m}$ decreased by $12.6-$ $14.8 \%$.

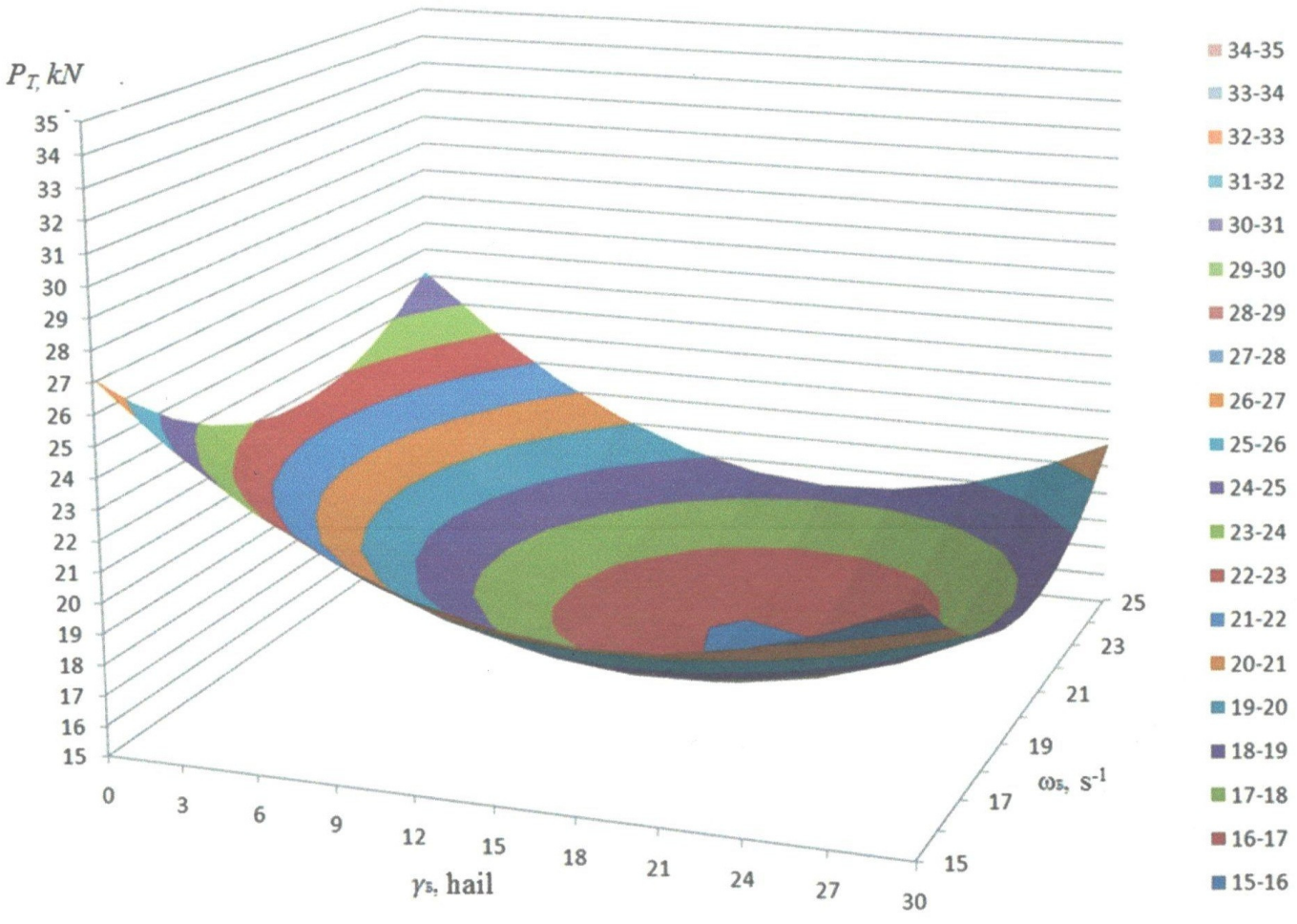

\section{Fig. 5. Surface of response of traction resistance of unit from angle of attack and angular speed of rotation of drum}

\section{Conclusions}

The design of the combined soil-cultivating unit providing plowing, crushing of soil blocks and mulching of the top soil is developed and investigated. The method of calculation of the constructive process parameters of the unit is offered. Mathematical model of the process of interaction of the active working body of the unit with the soil, regression models of dependence of quality of dyeing of the soil and traction resistance of the unit are received from its key parameters. Their optimum values are defined: operating speed 1.98-1.99 m. $\mathrm{s}^{-1}$, angular speed of rotation of the drum 20.1-20.7 with -1 and angle of attack of the working body 19-200, the soils of $92.3 \%$ providing quality of dyeing at the traction resistance of $15.8 \mathrm{kN}$. It is established that use of the unit has provided: increase in maintenance of soil units of 0.025 in size $0.001 \mathrm{~m}$ by $22.4-35.1 \%$, increase in porosity of the soil by 24.5-26.1\%, decrease in the contents in the soil of dusty fraction by 22.4-35.1\%. 


\section{References}

[1] Kyul E.V., Apazhev A.K., Kudzaev A.B., Borisova N.A. Influence of anthropogenic activity on transformation of landscapes by natural hazards. Indian Journal of Ecology, 2017, T. 44, No2, pp. 239-243.

[2] Апажев А.К., Хажметов Л.М., Шекихачев Ю.А., Фоменко С.А. Патент РФ No168218. МПК A01B49/02. Комбинированный почвообрабатывающий агрегат (Thecombinedsoilcultivatingunit), 2017, бюл. No3. (In Russian).

[3] Апажев А.К., Аппаев 3.Ш. Пути снижения тягового сопротивления лемешного плуга (Ways of decrease in traction resistance of a plow). Аграрный вестник Урала, 2012, No3, С. 24-25. (InRussian).

[4] Апажев А.К., Шекихачев Ю.А., Хажметов Л.М. Рациональные параметры и режимы работы комбинированного почвообрабатывающего агрегата (Rational parameters and operating modes of the combined soil-cultivating unit). Владикавказ: ФГБОУ ВО «Горский госагроуниверситет». Известия Горского государственного аграрного университета, 2016, T. 53, Ч. 2, C. 138-143. (In Russian).

[5] Апажев А.К., Шекихачев Ю.А., Хажметов Л.М. Результаты производственных испытаний комбинированного почвообрабатывающего агрегата (Results of production tests of the combined soil-cultivating unit). Сельский механизатор, 2016, No8, С. 10-11. (In Russian).

[6] Апажев А.К., Кошеев М.М. Комбинированные почвообрабатывающие агрегаты для предпосевной подготовки почвы (The combined soil-cultivating units for preseeding preparation of the soil). В сборнике: Инновации в агропромышленном комплексе. Материалы VI Межвузовской научно-практической конференции сотрудников и обучающихся аграрных вузов Северо-Кавказского Федерального Округа, посвященной 100-летию со дня рождения профессора 3.Х. Шауцукова, 2017, С. 10-12.(In Russian).

[7] Ашабоков Х.Х., Хажметов Л.М., Шекихачев Ю.А.Разработка агрегата для предпосевной подготовки почвы (Development of the unit for preseeding preparation of the soil). Современные научные исследования и разработки, 2017, No4 (12), С. 363-365.(InRussian).

[8] Аушев М.Х., Хамхоев Б.И., Хажметов Л.М., Шекихачев Ю.А., Кишев М.А., Эркенов А.Н., Твердохлебов С.А. Математическое моделирование процесса работы комбинированного почвообрабатывающего агрегата (Mathematical modeling of process of operation of the combined soil-cultivating unit). Политематический сетевой электронный научный журнал Кубанского государственного аграрного университета, 2014, No99, C. 266-295. (In Russian).

[9] Аушев М.Х., Хамхоев Б.И., Хажметов Л.М., Шекихачев Ю.А., Эркенов А.Н., Твердохлебов С.А. Агротехническая эффективность комбинированного почвообрабатывающего агрегата (Agrotechnical efficiency of the combined soil-cultivating unit). Политематический сетевой электронный научный журнал Кубанского государственного аграрного университета, 2014, No99, C. 429-448.(In Russian).

[10] Аушев М.Х., Хамхоев Б.И., Хажметов Л.М., Шекихачев Ю.А., Эркенов А.Н., Твердохлебов С.А.Обоснование конструктивно-технологической схемы комбинированного почвообрабатывающего агрегата для предпосевной подготовки почвы (Justification of the constructive and technological scheme of the combined soil-cultivating unit for preseeding preparation of the soil). Политематический сетевой электронный научный журнал Кубанского государственного аграрного университета, 2014, No99, С. 660-670.(In Russian). 